\title{
Pengaruh Pelatihan Social Skills terhadap Peningkatan Komunikasi dan Kerjasama pada Anak-Anak di RPTRA Anggrek Bintaro
}

\author{
Benita Ratih Meitya), Della Adelia ${ }^{2)}$, Ni Luh Putu Stephanie ${ }^{3)}$, Rania Pingky Ajrina Tirzi ${ }^{4)}$, \\ Rita Ria Lita ${ }^{5}$ \\ Program Studi Psikologi Universitas Pembangunan Jaya (UPJ), Bintaro \\ ${ }^{1}$ Email: benita.ratih@student.upj.ac.id \\ 2Email: della.adelia@student.upj.ac.id \\ ${ }^{3}$ Email: niluh.putu@student.upj.ac.id \\ ${ }^{4}$ Email: rania.pingky@student.upj.ac.id \\ ${ }^{5}$ Email: rita.rialita@student.upj.ac.id
}

\begin{abstract}
ABSTRAK
Kerjasama dan komunikasi adalah salah satu aspek dari sosial emosional yang berguna bagi anak usia 7-12 tahun untuk menunjang kemampuan sosial mereka. Kerjasama merupakan suatu aktivitas dalam kelompok kecil dimana terdapat kegiatan saling berbagi dan bekerja secara kolaboratif untuk menyelesaikan sesuatu sedangkan komunikasi adalah proses menyampaikan informasi dari satu orang ke orang lain baik mereka individual, grup, atau organisasi, dan mengubah opini, attitude, dan perilaku. Pelatihan ini ditujukan untuk meningkatkan social skills anak-anak usia sekolah (7-12 tahun), khususnya kemampuan dalam komunikasi dan bekerjasama. Pelatihan diselenggarakan selama dua hari di RPTRA Angrek, Bintaro pada tanggal 2 dan 3 Desember 2016. Peneliti menggunakan berbagai macam metode dalam menyampaikan materi tentang kerjasama dan komunikasi kepada subjek, antara lain: ceramah, presentasi, bercerita, games/permainan, bermain peran (role play), menonton film, diskusi kelompok, dan tanya jawab. Hasil dari pelatihan ini adalah kemampuan social skills (komunikasi dan kerjasama) anak-anak RPTRA Anggrek Bintaro mengalami peningkatan.
\end{abstract}

Kata kunci: kerjasama, komunikasi, social skill, pelatihan

\section{PENDAHULUAN}

Monks (dikutip dalam Setiawati \& Suparno, 2010) menjelaskan bahwa perkembangan kemampuan sosial anak dimulai pada masa pra sekolah sampai akhir sekolah dengan ditandai oleh meluasnya lingkungan sosial anak. Kemampuan sosial dan kerjasama sangat penting untuk anak, hal ini akan menjadi bekal saat anak memasuki dunia pergaulan yang lebih luas, dimana pengaruh teman-teman dan lingkungan sosial akan mempengaruhi kehidupannya (Adistyasari, 2013). Pendapat lain menjelaskan bahwa kemampuan sosial akan membentuk sikap sosial yang cenderung menetap dan sulit diubah (Hurlock dalam Muharromi, 2011). Hal ini mempengaruhi kemampuan anak dalam mengikuti kegiatan bermasyarakat, dan mempengaruhi kemampuan anak untuk diterima dalam kehidupan bermasyarakat, serta akan membentuk dan menentukan pola khas perilaku anak, serta mempengaruhi kepribadian anak (Hurlock dalam Muharromi, 2011).

Hurlock (dalam Purba, 2011) mendefinisikan kemampuan sosial sebagai suatu kemampuan atau kecakapan seseorang untuk berhubungan dengan orang lain dan untuk terlibat dalam situasisituasi sosial yang memuaskan. Kemampuan sosial merupakan suatu sarana untuk dapat diterima dalam masyarakat dan dengan kemampuan sosial seseorang menjadi peka terhadap berbagai situasi sosial yang dihadapinya. Sedangkan Santrock (2011) mengatakan kemampuan sosial adalah kemampuan individu untuk berinteraksi secara efektif dengan lingkungannya yang mencakup kemampuan anak untuk beradaptasi pada lingkungan yang dinamis dan untuk menganalisa ketika perilaku yang dipilih menjadi efektif.

Memasuki masa sekolah anak/siswa berupaya semakin ingin mengenal siapa dirinya dengan membandingkan dirinya dengan teman sebayanya. Jika proses itu tanpa bimbingan, anak akan cenderung sukar beradaptasi dengan lingkungannya. Makmun (Karuniasari \& others, 2010) 
mengatakan sekolah sebagai tempat tumbuh kembang anak memiliki tanggung jawab terhadap hal tersebut. Usia sekolah dasar dibagi menjadi dua kelas 2 yaitu kelas rendah antara usia $6-10$ tahun dan kelas tinggi antara usia $10-13$ tahun. Pada masa ini anak mulai menyesuaikan diri dengan lingkungan baru tanpa didampingi orang tua (Agustin \& others, 2014). Makmun (Karuniasari, 2010) mengatakan bahwa anak usia 9-12 tahun memiliki ciri perkembangan sikap mandiri sebagai tahap lanjut dari usia 6-9 tahun dengan ciri perkembangan sosial yang pesat. Soesilowindra (Karuniasari \& others, 2010) mengungkapkan bahwa tugas-tugas perkembangan yang harus tercapai pada masa kanak-kanak akhir yaitu kemampuan social-help skills dan play skill. Social-help skills untuk membantu orang lain di rumah, di sekolah, dan di tempat bermain seperti membersihkan halaman, merapikan meja dan kursi. Kedua hal tersebut akan menambah perasaan harga diri dan sebagai anak yang berguna hingga menjadikan anak suka bekerja sama (bersifat kooperatif). Play skill terkait dengan kemampuan motorik seperti melempar, menangkap, berlari, keseimbangan. Anak yang terampil dapat membuat penyesuaianpenyesuaian yang lebih baik di sekolah dan di masyarakat.

Perkembangan anak usia sekolah dasar merupakan kelanjutan dari masa awal anak. Permulaan masa pertengahan dan akhir anak ini yang ditandai dengan terjadinya perkembangan fisik motorik, kognitif, dan psikosial anak (Lismadiana, 2013). Pola perilaku sosial yang terlihat pada masa kanak-kanak awal, seperti yang diungkap oleh Hurlock (dalam Lismadiana, 2013) yaitu: kerjasama, persaingan, kemurahan hati, hasrat akan penerimaan sosial, simpati, empati, ketergantungan, sikap ramah, sikap tidak mementingkan diri sendiri, meniru, perilaku kelekatan. Tahap perkembangan menurut Erikson dan Piaget dapat membantu anak dalam mengembangkan kemampuan sosialnya termasuk saat bekerjasama dan berkomunikasi. Kemampuan berkerjasama anak, menurut teori perkembangan menurut Erikson terdapat pada tahap industry vs inferiority (Santrock, 2011).

Sedangkan kemampuan berkomunikasi anak, menurut Piaget, terdapat pada tahap tahap operasional kongkrit (Santrock, 2011). Nur Asma (dalam Hidayati, 2014) mengatakan bahwa kerjasama merupakan suatu aktivitas dalam kelompok kecil dimana terdapat kegiatan saling berbagi dan bekerja secara kolaboratif untuk menyelesaikan sesuatu. kerjasama merupakan berbagai usaha yang dilakukan manusia untuk menghasilkan berbagai perilaku yang terkait dengan interaksi sosial. Meilani (2014) mengatakan apabila kondisi anak dan lingkungan sosial dapat memfasilitasi atau memberikan peluang terhadap perkembangan anak secara positif maka anak akan dapat mencapai perkembangan sosial emosional dan kerjasama yang baik, begitu pula sebaliknya. Kerjasama dan komunikasi merupakan salah satu aspek dari social emosional.

Hurlock (dalam Meilani, 2014) menyatakan bahwa kerjasama anak dapat dibentuk saat anak mulai bermain bersama teman sebaya dan kooperatif, serta kegiatan kelompok mulai berkembang dan meningkat baik dalam frekuensi maupun lamanya berlangsung, bersamaan dengan meningkatkan kesempatan untuk bermain dengan anak lain. Nur Asma (Hidayati, 2014) mengatakan bahwa kerjasama merupakan suatu aktivitas dalam kelompok kecil dimana terdapat kegiatan saling berbagi dan bekerja secara kolaboratif untuk menyelesaikan sesuatu. Kerjasama merupakan berbagai usaha yang dilakukan manusia untuk menghasilkan berbagai perilaku yang terkait dengan interaksi sosial. Lungdren (dalam Purwaningsih, 2013) menjabarkan indikator kerjasama sebagai berikut: 1). Menyamakan pendapat dalam suatu kelompok sehingga mencapai suatu kesepakatan bersama yang berguna untuk meningkatkan hubungan kerja; 2) Mengambil giliran dan berbagi tugas. Hal ini berarti setiap anggota kelompok bersedia menggantikan dan bersedia mengemban tugas atau tanggung jawab tertentu dalam kelompok; 3) Berada dalam kelompok selama kegiatan kelompok berlangsung; 4) Mengerjakan tugas yang telah menjadi 
tanggung jawabnya agar tugas dapat diselesaikan tepat waktu; dan 5) Menyelesaikan tugas tepat waktu. Perkembangan kerjasama anak harus didukung karena ketika anak memiliki perasaan yang baik tentang dirinya, memiliki hubungan sosial yang positif dengan orang lain dan mengetahui bagaimana mengatur emosinya maka mereka akan lebih menampilkan perilaku yang positif.

Santrock, (2011) mengatakan ketika anak memasuki sekolah ia memperoleh kemampuan baru yang membuat mereka mampu belajar membaca dan menulis. Hal ini mencakup kemahiran berbicara tentang sesuatu yang tidak terlihat secara fisik, belajar mengenai arti sebuah kata, dan belajar bagaimana mengenali dan menghasilkan bunyi. Mereka mempelajari prinsip alphabet yaitu huruf-huruf melambangkan bunyi bahasa. Selama masa kanak-kanak pertengahan dan akhir terjadi perubahan cara mengorganisasikan kosakata secara mental. Contoh ketika diminta merespon kata 'anjing' anak kecil akan mengatakan menggonggong. Sekitar usia 7 tahun, anak mulai merespon sebuah kata yang merupakan bagian kelompok kata dan sekalian sebagai sebuah stimulus. Contoh anak akan merespon kata anjing dan 'kucing', hal ini menandakan bahwa anak mulai melakukan kategorisasi, kosakata mereka sebagai bagian dari kelompok kata (Santrock, 2011).

Menurut Santrock (2011), selama sekolah dasar anak-anak semakin memahami dan menggunakan tata bahasa yang kompleks. Contoh anak laki-laki yang mencium ibunya itu memakai topi. Mereka juga belajar menggunakan bahasa dengan cara yang lebih berkaitan satu sama lain, menghasilkan kata yang berkaitan. Mereka sudah mampu mengkaitkan kalimat satu dengan kalimat lainnya.sehingga dapat menghasilkan satu definisi dan narasi yang masuk akal. (Santrock, 2011) menjelaskan mengenai kosa kata dan tata bahasa yang berlangsung selama sekolah dsar disertai dengan perkembangan, kesadara, metalingkuistik yaitu merujuk pada pengetahuan bahasa kesadaran metalingkusitik anak-anak mampu memikirkan bahasa yang mereka gunakan, pemaham mengenai kata-kata yang mereka gunakan, dan mendefinisikannya.

Potter dan Perry (1997) mengatakan rata-rata anak usia 6 tahun memiliki kosakata sekitar 3000 kata yang cepat berkembang dengan meluasnya pergaulan dengan teman sebaya dan orang dewasa serta kemampuan bacanya. Menurut Golonka (2007) mayoritas anak-anak memiliki kosakata yang luas yaitu sekitar 13.000 kata saat usia 6 tahun. Di usia sekolah, terjadi perkembangan bahasa secara serentak dan dilanjutkan dengan perluasan kalimat melalui elaborasi antara frase kata benda dan kata kerja (Owens, 2008). Di masa perkembangan kognitif, anak dengan usia 6-10 tahun mampu berpikir kompleks. Anak yang memiliki kemampuan memahami kalimat sederhana akan mampu mengartikan kalimat yang lebih rumit dalam paragraf dan menulis beberapa kata untuk menyusun laporan dan cerita yang kompleks (Golonka, 2007).

Golonka (2007) mengatakan kemampuan bahasa masih terbatas pada hal yang konkrit dan berfokus pada kejadian "here and now". Sebelum berusia 9 tahun, kebanyakan anak memahami bahasa dengan harfiah. Sekitar usia 10 tahun, anak mampu memahami makna ganda dan hubungan antar kalimat Hal ini sesuai dengan perubahan kognitif pada anak usia sekolah adalah pada kemampuan untuk berfikir dengan cara logis tentang "here and now" dan bukan tentang abstraksi (Potter dan Perry, 1997). Salah satu bentuk perkembangan kognitif ialah perkembangan bahasa yang dapat membantu anak dalam berkomunikasi. Feldman (2007) mengemukakan beberapa indikator komunikasi pada anak usia 5-7 tahun, dan biasanya anak usia sekolah sudah dapat melakukan hal ini: 1) Anak dapat menggunakan slangwords; 2) Anak dapat mengeluarkan lelucon sederhana; 3) Anak dapat mengekspresikan kemarahan dengan tidak menggunakan bahasa agresif; 4) Anak dapat menjadi sadar terhadap kesalahan bahasa orang lain; 5) Anak 
dapat menceritakan antara hubungan gambar dengan yang terjadi; 6) Anak dapat menggunakan kata-kata yang bermakna; dan 7) Anak mulai tertarik pada belajar, produktifitas, dan membaca.

Penelitian sebelumnya yang dilakukan di RA Bustanul Athfal Kelas B menunjukkan bahwa anak sering kali mendapatkan kesulitan dalam berinteraksi dengan temannya dan orang dewasa lainnya di sekolah. Contoh, tidak mau menjawab saat ditanya guru, tidak mau bermain bersama teman sebaya, tidak mau mengalah dengan teman sebaya dan tidak mau mengikuti perintah dari guru (Muharromi, 2011). Hal tersebut sesuai dengan hasil observasi yang dilakukan oleh peneliti di RPTRA Anggrek Bintaro yaitu anak-anak berkomunikasi dengan bahasa kasar yang tidak seharusnya diucapkan, anak tidak menjawab pertanyaan sesuai dengan topik yang ditanyakan, anak-anak tidak mau bermain dengan anak lain di luar RPTRA.

Mengingat kemampuan sosial skills sangat penting bagi anak, khususnya kemampuan dalam bekerja sama dan berkomunikasi, maka peneliti tertarik untuk melakukan penelitian mengenai hal ini. Subjek pada penelitian ini yaitu anak 7-12 tahun yang beraktivitas di Ruang Publik Terpadu Ramah Anak (RPTRA) Anggrek, yang berlokasi di kelurahan Bintaro, kecamatan Pesanggrahan, Jakarta Selatan. Alasan peneliti memilih subjek dengan usia tersebut karena pada tahapan ini kemampuan sosial anak dalam berkomunikasi dan kerjasama sedang dalam masa pembentukan. Selain itu, RPTRA dibangun di tengah-tengah padat penduduk sehingga kemampuan berkomunikasi dan kerjasama sangat dibutuhkan dalam kemampuan sosialnya.

\section{METODE PENELITIAN}

Metode yang digunakan dalam pelatihan ini adalah kuasi eksperimental dengan metode pengumpulan data observasi dan wawancara. Observasi dan wawancara dilakukan berdasarkan indikator teori kerjasama dan komunikasi. Peneliti melakukan observasi di RPTRA sebanyak 3 kali pada bulan Oktober dan November 2016.

Indikator kerjasama yang digunakan dalam penelitian ini yaitu: (1) menyamakan pendapat dalam suatu kelompok sehingga mencapai suatu kesepakatan bersama yang berguna untuk meningkatkan hubungan kerja, (2) mengambil giliran dan berbagi tugas. Hal ini berarti setiap anggota kelompok bersedia menggantikan dan bersedia mengemban tugas atau tanggung jawab tertentu dalam kelompok, (3) berada dalam kelompok selama kegiatan kelompok berlangsung, (4) mengerjakan tugas yang telah menjadi tanggung jawabnya agar tugas dapat diselesaikan tepat waktu, (5) menyelesaikan tugas tepat waktu. Ada pun indikator dari komunikasi yang digunakan dalam penelitian ini yaitu: (1) anak dapat menggunakan slang words, (2) anak dapat mengeluarkan lelucon sederhana, (3) anak dapat mengekspresikan kemarahan dengan tidak menggunakan bahasa agresif, (4) anak dapat menjadi sadar terhadap kesalahan bahasa orang lain, (5) anak dapat menceritakan antara hubungan gambar dengan yang terjadi, (6) anak dapat menggunakan kata-kata yang bermakna, (7) anak mulai tertarik pada belajar, produktifitas, dan membaca.

Variabel penelitian yang digunakan pada pelatihan ini yaitu pelatihan social skills yang meliputi kemampuan komunikasi dan kerjasama. Variabel bebas dalam penelitian ini adalah social skills. Sedangkan variabel terikat yang digunakan dalam penelitian ini adalah peningkatan social skills. Subjek penelitian pada pelatihan ini adalah pengurus RPTRA sebagai data pendukung karena dalam penelitian ini tidak memberikan post-test dan pre-test dengan karakteristik sebagai berikut : (1) bekerja sebagai pengurus RPTRA Anggrek Bintaro, (2) bersedia untuk diwawancarai seputar anak RPTRA. Sedangkan subjek utama yang digunakan adalah 30 anak-anak RPTRA dengan karakteristik sebagai berikut: (1) karakteristik anak usia 7 sampai 12 tahun, (2) laki- laki 
dan perempuan, (3) melakukan aktivitas di RPTRA, mengikuti serangkaian kegiatan.

Prosedur penelitian dirancang seperti berikut:

\section{- Pra/sebelum pelatihan}

1.Peneliti mengunjungi RPTRA Anggrek untuk meminta izin dan mengatur jadwal untuk mengadakan pelatihan di RPTRA.

2.Peneliti melakukan wawancara kepada pegurus RPTRA dan observasi terhadap anak.

3.Peneliti merancang modul pelatihan yang memuat tujuan dan sasaran pembelajaran, aktivitas pembelajaran serta waktu yang dibutuhkan untuk pembelajaran.

4.Peneliti menyiapkan peralatan yang dibutuhkan pada saat perlatihan berlangsung.

\section{- Pelaksanaan pelatihan}

1. Peneliti melaksanakan pelatihan selama 2 hari di RPTRA Anggrek Bintaro.

2. Peneliti mengobservasi subjek yang terlibat dalam pelatihan.

\section{- Pasca pelatihan}

Melakukan evaluasi melalui observasi dan tanya jawab pada setiap sesi oleh fasilitator. Evaluasi ini membahas respon-respon subyek selama mengikuti pelatihan, memantau pemahaman subyek terhadap materi pelatihan serta untuk melihat kekurangan dan kelebihan dari kegiatan pelatihan.

\section{HASIL DAN PEMBAHASAN}

Hasil penelitian berdasarkan indikator kerjasama yaitu : (1) menyamakan pendapat dalam suatu kelompok sehingga mencapai suatu kesepakatan bersama yang berguna untuk meningkatkan hubungan kerja. Pada indikator ini selama penelitian anak mampu menyamakan pendapat dalam sebuah kelompok menggunakan metode diskusi dan studi kasus sederhana, (2) mengambil giliran dan berbagi tugas. Hal ini berarti setiap anggota kelompok bersedia menggantikan dan bersedia mengemban tugas atau tanggung jawab tertentu dalam kelompok. Pada indikator ini selama penelitian anak dapat bekerjasama dengan baik untuk mencapai kemenangan melalui metode bermain yaitu pingpong air. (3) mengerjakan tugas yang telah menjadi tanggung jawabnya agar tugas dapat diselesaikan tepat waktu. Pada indikator ini anak mampu berada di dalam kelompok selama penelitian berlangsung dengan metode bermain yaitu menara sedotan dengan waktu yang relatif lama. Ketiga indikator yang telah dijelaskan selalu berkaitan dengan indikator berada dalam kelompok selama kegiatan kelompok berlangsung.

Ada pun indikator dari komunikasi yang digunakan dalam penelitian ini yaitu : (1) anak dapat menggunakan bahasa informal. Pada indikator ini anak mampu membedakan bahasa yang digunakan untuk orangtua dan teman. Metode yang digunakan adalah pengelompokkan kalimat. (2) anak dapat mengeluarkan lelucon sederhana. Pada indikator ini anak mampu mengeluarkan lelucon sederhana setelah menonton tayangan humor yang ditayangkan oleh peneliti. (3) anak dapat mengekspresikan kemarahan dengan tidak menggunakan bahasa agresif, (4) anak dapat menjadi sadar terhadap kesalahan bahasa orang lain. Pada indikator tiga dan empat peneliti menggabungkan kedua indikator karena saling berkaitan satu sama lain. Dari kedua indikator ini anak mampu mengekspresikan kemarahan dan menyadari kesalahan penggunaan bahasa. Metode yang digunakan adalah menonton film pendek dan presentasi dari fasilitator. (5) anak dapat menceritakan antara hubungan gambar dengan yang terjadi. Pada indikator ini anak telah mampu menceritakan hubungan antara gambar dan kejadian nyata menggunakan metode game "story telling”. (6) anak dapat menggunakan kata-kata yang bermakna. Pada indikator ini anak telah 
mampu menggunakan kata-kata yang bermakna dan memahami makna ganda dengan menggunakan metode game "puzzle kata makna ganda".

Hasil wawancara dan observasi yang dilakukan pada pengurus RPTRA yang dilakukan pada bulan Oktober dan November atau kurang lebih 3 kali kunjungan ke RPTRA sebagai data pendukung yaitu: 1) pengurus RPTRA ramah, responsif, terbuka, dan komunikatif dalam menjawab beberapa pertanyaan singkat yang diajukan oleh peneliti untuk mengetahui gambaran seputar RPTRA, 2) anak-anak di RPTRA sudah dibekali norma kesopanan dalam arti mengalah kepada yang lebih muda dan menghormati yang lebih tua,3) anak-anak RPTRA diberikan kegiatan kursus seperti Bahasa Inggris, Mengaji, Matematika, dan kegiatan untuk mengembangkan kognitif, seperti: belajar bersama setiap UTS dan UAS, mengerjakan PR bersama serta kegiatan lainnya, 4) balai RPTRA digunakan untuk kegiatan masyrakat yang ada di sekitarnya tidak hanya terbatas untuk warga RPTRA Anggrek,5) balai RPTRA dapat digunakan segala umur baik tua ataupun muda sesuai dengan kegiatan yang telah berlangsung.

Hasil wawancara dengan pengurus RPTRA menyatakan bahwa anak-anak yang beraktivitas di RPTRA Anggrek memiliki kemampuan kerjasama tetapi masih perlu di tingkatkan kembali. Kerjasama pada anak RPTRA dapat dilihat saat anak-anak tersebut bermain lego, membereskan mainan, melakukan operasi semut, melakukan kerja bakti di RPTRA. Selanjutnya wawancara mengenai komunikasi pengurus RPTRA mengatakan bahwa komunikasi anak di RPTRA juga terlihat terlihat baik seperti: 1) pada saat anak menggunakan kata-kata yang sopan kepada yang lebih tua, 2) selalu memberi salam dan menyapa para pengurus dan tamu yang berada dilingkungan RPTRA,3) aktif bertanya kepada orang yang lebih dewasa jika mereka mengalami kesulitan.

Kegiatan pelatihan dilaksanakan selama 2 kali sesi pada tanggal 2 dan 3 Desember 2016. Hari pertama pelatihan dimulai pada jam 14.00 WIB sampai 17.00 WIB. Pada hari pertama, materi kerja sama diberikan dalam 3 sesi. Sesi 1 adalah menyamakan pendapat dalam suatu kelompok (10 menit); Sesi 2 mengambil giliran dan berbagi tugas (20 menit); dan Sesi 3 mengerjakan tugas yang sesuai dengan tanggung jawabnya (20 menit). Pada hari kedua pelatihan dimulai pukul 15.00 WIB sampai 18.00 WIB. Materi-materi mengenai komunikasi diberikan dalam 5 sesi. Sesi 1 adalah anak dapat mengungkapkan humor/lelucon sederhana selama (5 menit); Sesi 2 anak dapat menggunakan bahasa informal selama ( 15 menit); Sesi 3 anak dapat mengekpresikan kemarahan dan menyadari kesalahan bahasa (20 menit); Sesi 4 anak dapat mengunakan kata-kata yang bermakna dan memahami hubungan antara kalimat (10 menit); dan Sesi 5 anak memahami tata bahasa yang lebih kompleks dan menceritakan hubungan gambar dengan kejadian nyata (30 menit). Peneliti menggunakan berbagai macam metode dalam menyampaikan materi tentang kerja sama dan komunikasi kepada subjek, antara lain: ceramah, presentasi, bercerita, games/permainan, bermain peran (role play), menonton film, diskusi kelompok, dan tanya jawab.

\section{KESIMPULAN}

Kesimpulan yang dapat diambil dari hasil pelatihan kerjasama pada anak-anak di RPTRA Anggrek adalah (1) anak RPTRA mampu menjalankan berbagai sesi sesuai indikator, (2) kerjasama yang dilakukan subjek sudah cukup baik terlihat saat fasilitator memberikan instruksi kepada subyek, mereka dapat memahami instruksi yang diberilkan oleh fasilitator. (3) subjek penelitan cukup antusias terhadap sesi pelatihan yang dilakukan oleh peneliti. (4) subjek ramah dan responsif sehingga sangat membantu fasilitator untuk memfasilitasi kegiatan dan beradaptasi dengan mudah. 
Kesimpulan yang dapat diambil dari hasil pelatihan komunikasi pada anak-anak di RPTRA Anggrek adalah (1) komunikasi yang digunakan subjek cukup baik tetapi bahasa yang digunakan kurang tepat. (2) pada pelatihan ini, sesi diberikan lebih banyak dan membuat konsentrasi subjek berkurang sehingga fasilitator melakukan ice breaking di tengah sesi pelatihan. (4) secara keseluruhan tujuan pelatihan ini sudah tercapai. Keterbatasan dari penelitian ini peneliti tidak melakukan pre-test dan post-test secara kuantitatif (melalui kuesioner, skala atau panduan) dikarenakan subjek yang dipilih adalah anak-anak. Sebagai data pendukung, pengurus RPTRA merespon dengan baik pelatihan yang diadakan dan menyiapkan peserta pelatihan sehingga pelatihan diselenggarakan dengan lancar.

\section{REFERENSI}

Adistyasari, R. (2010) Meningkatkan keterampilan sosial dan kerja sama anak dalam bermain Angin Puyuh. Skripsi tidak dipublikasikan. Fakultas Ilmu Pendidikan Universitas Negri Semarang, Semarang, Indonesia.

Agustin. A, \& Padmomartono. S, \&Windrawanto., Y. (2014). Meningkatkan perilaku prososial anak usia 10-12 tahun melalui terapi bermain di PPA AGAPE 10-847 Salatiga. Diakses dari: http://repository.uksw.edu/bitstream/123456789/6418/2/ART_AKM\%20Agustin,\%20S\%20 Padmomartono,\%20Y\%20Windrawanto_Meningkatkan\%20Perilaku\%20Prososial_fulltext. pdf.

Astuti, T, Y. (2014) Meningkatkan kemampuan kerja sama melalui permainan menyusul puzzle berkelompok di Rhaudhatul Athfal Masyithoh Kantongan Kelompok A. Diakses dari: http://eprints.uny.ac.id/14245/1/Tri\%20Yuni\%20Astuti\%20_10111247038.pdf.

Herdiansyah, H. (2010). Metodologi penelitian kualitatif untuk ilmu-ilmu sosial. Jakarta. Salemba Humanika.

Hidayati, W. (2014). Upaya meningkatkan kemampuan kerjasama anak melalui permainan tradisional pada kelompok A TK ABA Ledok I Kulon Progo tahun ajaran 2013/2014.PG $P A U D$. Diakses dari: http://eprints.uny.ac.id/13562/1/WAHYU\%20HIDAYATI_11111247035.pdf.

Ibda, F. (2015) Perkembangan kognitif: teori Jean Piaget. Intelektualita, 3(1). Diakses dari: http://jurnal.ar-raniry.ac.id/index.php/intel/article/view/197

Kumar, R. (2011). Research Methodology: A Step-by- Step Guide for Beginners (3 ${ }^{\text {rd }}$ ed.). Washington: Sage.

Kurniasari, D. (2010). Pendekatan pembelajaran Beyond Center and Circle Time (BCCT) di sentra persiapan dalam upaya persiapan menulis dasar. Skripsi tidak dipublikasikan. Fakultas Keguruan dan Ilmu Pendidikan Universitas Muhammadiyah Surakarta, Yogyakarta, Indonesia.

Lismadiana. (2013). Peran perkembangan motorik pada anak usia dini. Diakses dari: http://staff.uny.ac.id/sites/default/files/penelitian/Dr.\%20Lismadiana,\%20M.Pd./Jurnal\%20Il miah\%20Keolahragaan\%20Lismadiana.pdf.

Meilani, L. (2014). Meningkatkan Kemampuan Bekerjasama pada Kelompok Bermain Melalui Kegiatan Memasak (Cooking Class): Penelitian Tindakan Kelas di Kober Azkiya Usia 3-4 Tahun Pada Tahun Ajaran 2013/2014 Di Kecamatan Dayeuh Kolot Kabupaten Bandung. Diakses dari: http://repository.upi.edu/15568/.

Muharromi, D. S. (2011). Efektivitas Pembelajaran Kooperatif Teknik Mencari Pasangan terhadap Kemampuan Sosialisasi Anak Usia Dini: Penelitian Kuasi Eksperimen pada Siswa RA Siti Khadijah dan RA Bustanul Athfal Kecamatan Cililin Bandung Barat Tahun Ajaran 2009/2010. Universitas Pendidikan Indonesia : Fakultas Ilmu Pendidikan. Skripsi tidak dipublikasikan. 
Nibella, A. V. (2014). Peran Komunikasi Verbal dan Non Verbal dalam Penanaman Akhlak pada anak usia Dini ditaman Kanak-kanak Islam Al-Muttaqin. Diakses dari: http://repository.uinjkt.ac.id/dspace/bitstream/123456789/26261/1/ANDI\%20VIOLETTA\% 20NIBELLA-FDK.pdf.

Rahma,K. M. (2012). Perbedaan Kompetensi Komunikasi Antara Remaja Awal Bilingual Dengan Monolingual.Skripsi tidak dipublikasikan. Fakultas Psikologi Universitas Sumatera Utara, Medan, Indonesia.

Santrock, J. W. (2011). Life-span Development (13 ${ }^{\text {th }}$ ed.). University of Texas, Dallas: Mc Graw-Hill

Saudia, A. (2009). Komunikasi Interpersonal Yang Efektif Pada Kelompok Kerja X. Jurnal Program Studi Psikologi Universitas Gunadarma.

Setiawati. E, \& Suparno. (2010). Interaksi sosial dengan teman sebaya pada anak homeschooling dan anak sekolah reguler (Study deskriptif komparatif). Diakses dari: http://journals.ums.ac.id/index.php/indigenous/article/view/1609/1145.

Sudarsih, W. (2011). Keterampilan sosial siswa ADHDDI Sekolah Dasar Negeri Y Pangkalpinang. Diakses dari: http://repository.upi.edu/9748/.

Willig, C. (2001). Introducing qualitative research in psychology: Adventures in theory and method. Buckingham: Open University Press.

Wonodihadrjo, F. (2014). Komunikasi kelompok yang mempengaruhi konsep diri dalam komunitas Cosplay "COSURA" Surabaya. Jurnal Program Studi Ilmu Komunikasi Universitas Kristen Petra, Surabaya. 